\title{
Effect of light on biosynthesis of alkamide, caffeic acid derivatives and echinacoside in Echinacea purpurea L. callus cultures*
}

\author{
Muhammed Akif AÇIKGÖZ1, Şevket Metin KARA, Ebru BATI AY², Sedanur ODABAŞ1 \\ ${ }^{1}$ Ordu University, Faculty of Agriculture, Department of Field Crops, Ordu, Turkey \\ ${ }^{2}$ Amasya University, Suluova Vocational School, Program of Medicinal and Aromatic Plants, Suluova-Amasya, Turkey
}

${ }^{*}$ The present study was supported by Scientific Research Projects Unit (BAP) of Ordu University, with the number of AR-1340 BAP Project. The study was oral presented at The $4^{\text {th }}$ International Mediterranean Symposium on Medicinal and Aromatic Plants, April 18-22, 2018, Antalya, Turkey.

Alınış tarihi: 4 Haziran 2018, Kabul tarihi: 18 Ekim 2018

Corresponding author: Şevket Metin KARA, e-posta:smkara58@hotmail.com

\begin{abstract}
Light is not only effective in photosynthesis, growth and development, but also play an important role in biosynthesis of primary and secondary metabolites. The present research was aimed to determine effect of light on biosynthesis of alkamide, caffeic acid derivatives and echinacoside in cell suspension cultures of Echinacea purpurea L. Stem explants derived from sterile plants were subjected to callus culture in a B5 media supplemented with $1.0 \mathrm{mg} / \mathrm{L}$ BAP and $2.0 \mathrm{mg} / \mathrm{L}$ NAA. Afterward, 8-day cell cultures were incubated in light and dark environments and cell harvesting, with a three-day interval, was carried out five times. The contents of alkamide, caffeic acid derivatives and echinacoside were determined using HPLC. Alkamide, caftaric acid and echinacoside content increased regularly with light application. Light application increased alkamide content by $57 \%$, as an average, compared to darkness. The cell cultures exposed to 12 days of incubation in light produced the highest alkamide content, with a 2.11-fold increase, compared to dark. Subjecting the cell cultures to light for 12 days resulted in $70 \%$ and $63 \%$ increases in caftaric acid and echinacoside. This study showed that light application in Echinacea purpurea L. cell suspension culture had a great potential for increasing some important phytochemicals.
\end{abstract}

Key words: Caftaric acid, elicitor, purple coneflower, phytochemical compounds, secondary metabolites
Işığın Echinacea purpurea L. kallus kültüründe alkamide, kafeik asit türevleri ve echinacoside biyosentezi üzerine etkisi

\section{Öz}

Işık sadece fotosentez, büyüme ve gelişmede etkili değildir, aynı zamanda birincil ve ikincil metabolizma ürünlerinin biyosentezinde de önemli bir rol oynamaktadır. Bu araştırmanın amacı ışığın Echinacea purpurea L. hücre süspansiyon kültüründe alkamide, kafeik asit türevleri ve echinacoside biyosentezine etkisini tespit etmektir. Steril bitkilerin gövde eksplantlarından kalluslar elde edilmiş ve $1.0 \mathrm{mg} / \mathrm{L}$ BAP ve $2.0 \mathrm{mg} / \mathrm{L}$ NAA ilave edilmiş B5 ortamında kültüre alınmışlardır. Daha sonra, 8 günlük hücre kültürleri, aydınlık ve karanlık ortamlarda inkübe edilmiştir ve hücreler, üç günde bir olmak üzere, toplamda beş kez hasat edilmiştir. Alkamide, kafeik asit türevleri ve echinacoside içerikleri HPLC ile belirlenmiş̧ir. Alkamide, kaftarik asit ve echinacoside içeriği ışık uygulamalarıyla düzenli olarak artmıştır. Işık uygulaması ile alkamide içeriği karanlık ortama göre ortalama olarak \%57 artmıștır. En yüksek alkamide birikimi ışıkta 12 günlük inkübasyona maruz bırakılan hücre kültüründe tespit edilmiş ve karanlık ortama göre 2.11 katlık bir artış gerçekleşmiștir. Hücre kültürlerinin 12 gün süreyle ışığa maruz bırakılması, kaftarik asit ve echinacoside birikiminde \%70'lik ve \%63'lük bir artışa yol açmıştır. Bu araştırma, ışık uygulamasının Echinacea purpurea L. hücre süspansiyon kültüründe bazı önemli fitokim- 
yasalların artırılmasında büyük bir potansiyele sahip olduğunu göstermiştir.

Anahtar kelimeler: Kaftarik asit, elisitör, koni çiçeği, fitokimyasal bileșikler, sekonder metabolitler

\section{Introduction}

Multipurpose multi-use of bioactive substances, called secondary metabolites, found in the chemical structures of plants used for medicinal and aromatic purposes make these plants rather important in many different ways. Secondary metabolites obtained directly from plants grown in natural habitat are produced in a great number and variety in plants. These phytochemicals, varying according to plant species, variety, plant organ, growing stage, harvest time and postharvest processes and also prevailing climatic and soil factors, are greatly affected positively or negatively by the environmental conditions surrounding the plants. In this case, the produced compounds are hardly difficult to be in the same quality standards (Murthy et al., 2014; Gehlot et al., 2017). Cell suspension cultures, one of the most common tissue culture applications, may lead to obtain these compounds in specific quality standards, generate new compounds not found in original plant, and produce commercially these economically highly valuable phytochemicals independently of ecological conditions (Srivastava et al., 2011). Echinacea purpurea has recently gained an increasing interest by virtue of its important phytochemicals such as caffeic acid and alkamide (Xu et al., 2014; Manayi et al., 2015; El Aal et al., 2016). In Echinacea species, so far, the effect of several elicitors (U.V B and C rays, light intensity, jasmonic acid, methyl jasmonate, salicylic acid, and incubation temperature and duration) on alkamide, caffeic acid derivatives and echinacoside accumulation has been investigated using adventitious root cultures. At the end of these studies, appropriate protocols for the production of these valuable phytochemicals with bioreactors have been developed (Wu et al., 2007; Romero et al., 2009; Liu et al., 2012; Gualandi et al., 2014). However, the effects of light applications on the accumulation of phytochemicals in cell suspension cultures have not been adequately investigated (El-Aal et al., 2016). In view of this, the present research was carried out to determine the effects of light and dark conditions on accumulation of phytochemicals such as alkamide, caffeic acid derivatives and echinacoside along with cell growth and cell viability of Echinacea purpurea using cell suspension cultures.

\section{Materials and Methods}

Echinacea purpurea $\mathrm{L}$. seeds were germinated in a medium supplemented with $2.0 \mathrm{mg} / \mathrm{L} \mathrm{BAP}+0.01$ $\mathrm{mg} / \mathrm{L} \mathrm{IBA}+2.0 \mathrm{mg} / \mathrm{L} \mathrm{GA}_{3}$ and sterile plantlets were grown. The leaf and stem explants of these sterile plantlets were cultured in MS and B5 media containing different combinations of plant growth regulators (BAP with NAA and NAA with KIN). Each combination was planted in 4 petri dishes including 10 explants and cultured at $25^{\circ} \mathrm{C}$ and $16 / 8 \mathrm{~h} \mathrm{light/dark}$ condition for 4 weeks. Thereafter, the obtained calluses were sub-cultured twice in hormone free conditions. The calluses formed after eight weeks following subculture were evaluated in terms of callus weight and callus forming explant ratio to determine the most effective growth medium, hormone combination, and explant source. As result, the combination of B5 medium supplemented with $1.0 \mathrm{mg} / \mathrm{L} \mathrm{BAP}$ $+2.0 \mathrm{mg} / \mathrm{L}$ NAA and stem explant was used to produce cell suspension cultures.

\section{Preparation of cell suspension culture creation}

The obtained calluses were weighted to $0.5 \mathrm{~g}$ in a sterile cabinet and placed in a $250 \mathrm{~mL}$ Erlenmeyer containing $125 \mathrm{~mL}$ of liquid nutrient medium. Afterwards, the cell cultures were matured for 8 days on a rotary shaker with an average speed of $105 \mathrm{rpm}$ and then they were cultured at $25{ }^{\circ} \mathrm{C}$ with a $10000 \mathrm{Lux}$ luminous condition. The control cells were cultured at $25^{\circ} \mathrm{C}$ in darkness. In both light and dark environments, the samples were taken 5 times (in the $1^{\text {st }}, 3^{\text {rd }}$, $6^{\text {th }}, 9^{\text {th }}$ and $12^{\text {th }}$ days) and the first day samples were obtained 8 hours after incubation. The contents of alkamide, caffeic acid derivatives (caftaric, chlorogenic, and cichoric acid) and echinacoside in harvested samples were determined using Prominence LC-20A Modular HPLC system with L-2400 UV detector and $100 \mathrm{RP}-18$ e column $(250 \mathrm{~mm} \times 4.6 \mathrm{~mm} \times 5$ $\mu \mathrm{m}$, Shimadzu). Flow rate was $1.5 \mathrm{~mL} / \mathrm{min}$ and wavelength of the UV-detector was arranged to 330 $\mathrm{nm}$. The device was first given a standard of compounds and mass fragments and retention times were determined. Calibration curves of the compounds were then drawn and the amount of samples was determined as $\mu \mathrm{g} / \mathrm{g} \mathrm{dw}$.

\section{Determination of cell growth and viability}

Cell growth was determined by the average number of cells $(\mathrm{n})$ and cell dry weight $(\mathrm{g} / \mathrm{L})$. The number of 
cells was determined with the Nageotte counting chamber using the below formula of Moroff et al. (1994).

$$
\mathrm{n}=\sum_{i=1}^{40} c \cdot 20 \cdot \mathrm{sf}
$$

Where,

$\mathrm{n}$ : the average number of cells

c: the number of cells counted in each rectangular

sf: dilution factor

The cell dry weight was obtained by weighting the filtered cells kept in an oven at $55^{\circ} \mathrm{C}$ for 48 hours. Cell viability was determined using trypan blue staining technique developed by Laloue et al. (1980). According to this technique, $50 \mu \mathrm{l}$ of cell suspension culture, $125 \mu \mathrm{l}$ of trypan blue, and $75 \mu \mathrm{l}$ of phosphate buffer were added to the Eppendorf tube in order to increase the staining efficiency while keeping the cells alive in during counting. The data were analyzed through a one-way ANOVA using Minitab 17 statistical software program. The means were compared with the use of Duncan's Multiple Range Test.

\section{Results and Discussion}

The effect of light and dark condition along with incubation period on alkamide, caftaric acid, echina- coside, cell number and cell dry weight was statistically significant, but not on cell viability (Table 1 and Table 2). The amount of alkamide ( $\mu \mathrm{g} \mathrm{g}^{-1} \mathrm{dw}$ ) increased steadily in both the dark and the light conditions, depending on the incubation period. In darkness, the amount of alkamide in the starting culture was $166.09 \mu \mathrm{g} \mathrm{g}^{-1}$, but increased to $250.90 \mu \mathrm{g} \mathrm{g}^{-1}$ after 12 days of incubation. In light application, the amount of alkamide, which was $184.44 \mu \mathrm{g} \mathrm{g}^{-1}$ in the starting culture, increased to $530 \mu \mathrm{g} \mathrm{g}^{-1}$ at the end of $12^{\text {th }}$ day of culture. The highest accumulation of alkamide was found at the end of the $12^{\text {th }}$ day in both dark and light environments and the amount of alkamide deposited in light medium was found to be $279.10 \mu \mathrm{g} \mathrm{g}^{-1}$ higher than those in dark. Compared with light and dark environments, higher caftaric acid accumulation was observed in light, with a significant increases starting from the first day of incubation. In light medium, the amount of caftaric acid, which was $38.60 \mu \mathrm{g} \mathrm{g} \mathrm{g}^{-1}$ in the starting culture, reached to $120.60 \mu \mathrm{g} \mathrm{g}^{-1}$, increasing 3.12 fold at the end of a 12-day culture. On the other hand, the amount of caftaric acid went up over $71 \%$ from $33.50 \mu \mathrm{g} \mathrm{g}^{-1}$ in the starting culture to $57.40 \mu \mathrm{g} \mathrm{g}^{-1}$ after 12 days of incubation, in dark condition.

Table 1. Alkamide, caftaric acid and echinacoside contents of Echinacea purpurea L. cell suspension cultures stored at dark and light conditions for several days

\begin{tabular}{|c|c|c|c|c|}
\hline Medium & Incubation period (day) & Alkamide $\left(\mu \mathrm{g} \mathrm{g}^{-1} \mathrm{dw}\right)$ & Caftaric acid $\left(\mu \mathrm{g} \mathrm{g}^{-1} \mathrm{dw}\right)$ & Echinacoside $\left(\mu \mathrm{g} \mathrm{g}^{-1} \mathrm{dw}\right)$ \\
\hline \multirow{5}{*}{ Dark } & 1 & $166.09 \mathrm{f}^{* *}$ & $33.50 \mathrm{f} * *$ & $67.20 \mathrm{~g}^{* *}$ \\
\hline & 3 & $195.20 \mathrm{f}$ & $35.20 \mathrm{f}$ & $72.34 \mathrm{f}$ \\
\hline & 6 & 200.78 ef & $44.12 \mathrm{ef}$ & $80.55 \mathrm{de}$ \\
\hline & 9 & $225.87 \mathrm{~d}$ & $51.33 \mathrm{de}$ & $82.36 \mathrm{~d}$ \\
\hline & 12 & $250.90 \mathrm{~d}$ & $57.40 \mathrm{~d}$ & $84.87 \mathrm{~d}$ \\
\hline Mean & & $207.77 \mathrm{~B} * *$ & $44.30 \mathrm{~B}^{* *}$ & $77.46 \mathrm{~B}^{* *}$ \\
\hline \multirow{5}{*}{ Luminous } & 1 & $184.44 \mathrm{f}$ & $38.60 \mathrm{f}$ & 70.52 ef \\
\hline & 3 & $255.64 \mathrm{~d}$ & 44.20 ef & $80.40 \mathrm{~d}$ \\
\hline & 6 & $387.26 \mathrm{c}$ & $74.40 \mathrm{c}$ & $120.80 \mathrm{c}$ \\
\hline & 9 & $458.43 \mathrm{~b}$ & $100.92 \mathrm{~b}$ & $164.40 \mathrm{~b}$ \\
\hline & 12 & $530.00 \mathrm{a}$ & $120.63 \mathrm{a}$ & $196.31 \mathrm{a}$ \\
\hline Mean & & $363.15 \mathrm{~A}$ & $75.40 \mathrm{~A}$ & $126.49 \mathrm{~A}$ \\
\hline
\end{tabular}

$*^{*}, *$ : The means with the same lower and upper case letter in the same column are not significantly different from each other $(\mathrm{P}>0.05$ and $\mathrm{P}>0.01$, respectively).

The content of echinacoside showed an overall increase in dark and light environments, depending on the period of incubation; the longer the period of culture, the higher the content of echinacoside. In the dark, the amount of echinacoside in the initial culture was $67.20 \mu \mathrm{g} / \mathrm{g}$, whereas it increased to $80.51 \mu \mathrm{g} / \mathrm{g}$ at the 6th day and to $84.87 \mu \mathrm{g} / \mathrm{g}$ at the $12^{\text {th }}$ day. The echinacoside content of $70.52 \mu \mathrm{g} / \mathrm{g}$ in the starting culture of the luminous medium reached to the levels of $120.80 \mu \mathrm{g} / \mathrm{g}$ in the $6^{\text {th }}$ day and 196.32 $\mu \mathrm{g} / \mathrm{g}$ in the $12^{\text {th }}$ day. In general, the comparison of light and dark conditions indicated that light application was more effective on alkamide, caftaric acid echinacoside accumulation than dark (Table 1). The higher number of cells was counted in the illuminated environment and it showed significant increases starting from the $1^{\text {st }}$ day of culture, in comparison to darkness. In light condition, the number of cells in the starting culture was 85.40 and increased to 95.40 and 102.76 at the 6 th and the $12^{\text {th }}$ day, respec- 
tively. The lowest number of cells, on the other hand, was obtained from the initial culture of dark and light applications, as 84.50 and 85.40, respectively. Depending on the period of incubation, cell dry weights increased in the light and dark conditions.
While respective dry weights were $12.33 \mathrm{~g} / \mathrm{L}$ and $12.55 \mathrm{~g} / \mathrm{L}$ of the cells incubated at 9 and 12 days in light, these values were found to be as $10.70 \mathrm{~g} / \mathrm{L}$ and $11.12 \mathrm{~g} / \mathrm{L}$ after 9 and 12 days, respectively (Table 2).

Table 2. Cell number, cell dry weight and cell viability in Echinacea purpurea L. cell suspension cultures stored at dark and light conditions for several days

\begin{tabular}{|c|c|c|c|c|}
\hline Medium & Incubation period (day) & Cell number & Cell dry weight (g/L) & Cell viability (\%) \\
\hline \multirow{5}{*}{ Dark } & 1 & $84.50 \mathrm{f}^{* *}$ & $9.22 \mathrm{~d}^{* *}$ & 98.22 \\
\hline & 3 & $84.21 \mathrm{f}$ & $9.30 \mathrm{~d}$ & 97.55 \\
\hline & 6 & $85.30 \mathrm{f}$ & $9.44 \mathrm{~d}$ & 98.30 \\
\hline & 9 & $88.40 \mathrm{de}$ & $10.70 \mathrm{bc}$ & 99.42 \\
\hline & 12 & $91.82 \mathrm{bc}$ & $11.12 \mathrm{~b}$ & 98.50 \\
\hline Mean & & $91.83 \mathrm{~B}^{*}$ & $9.96 \mathrm{~B} *$ & 98.41 \\
\hline \multirow{5}{*}{ Luminous } & 1 & $85.40 \mathrm{f}$ & $9.24 \mathrm{~d}$ & 98.54 \\
\hline & 3 & $88.70 \mathrm{e}$ & $10.42 \mathrm{c}$ & 99.42 \\
\hline & 6 & $95.40 \mathrm{~cd}$ & $11.20 \mathrm{~b}$ & 98.50 \\
\hline & 9 & $98.20 \mathrm{~b}$ & $12.33 \mathrm{a}$ & 97.56 \\
\hline & 12 & $102.76 \mathrm{a}$ & $12.55 \mathrm{a}$ & 98.72 \\
\hline Mean & & $94.09 \mathrm{~A}$ & $11.15 \mathrm{~A}$ & 98.55 \\
\hline
\end{tabular}

$*, * *$ The means with the same lower and upper case letter in the same column are not significantly different from each other $(\mathrm{P}>0.05$ and $\mathrm{P}>0.01$, respectively).

Light, perceived by plants through a variety of photoreceptors that detect red and infrared lights, is one of the most important environmental factors that regulate the growth, development and metabolism of plants (Chaves et al., 2011; Heijde and Ulm, 2012). The response of plant cells to light occurs by virtues of interaction between proteins of COP1/SPA connected with PAP proteins. In darkness, these two proteins are suppressed by ubiquitin ligase. In light conditions, however, SPA1 and SPA2 proteins become unstable and consequently COP1 proteins become more active (Shalitin et al., 2002; Balcerowicz et al., 2011; Weidler et al., 2012). This leads to various metabolic activities such as chlorophyll and anthocyanin biosynthesis as well as growth and development responses such as phototropism and flowering induction (Kami et al., 2010).

Light is not only effective in photosynthesis, growth and development, but also has an important role in biosynthesis of primary and secondary metabolites by increasing PAL activity in cell cultures (Halliday and Fankhauser, 2003; Khan et al., 2013). Many phenolic compounds, caffeic acid, cinnamic acid, flavonoids, anthocyanin and caffeic acid derivatives (cichoric acid, caftaric acid, chlorogenic acid and caffeic acid) are produced by the phenylpropanoid pathway initiated by PAL (Winkel-Shirley, 2001; Shohael et al., 2006; Sreelakshmi and Sharma, 2008). According to previous studies (Zhao et al., 2010; Tariq et al., 2014; Georgieva et al., 2015; Ahmad et al., 2016) cell growth, the contents of anthocyanin, total phenolic substance, alcamide, caftaric acid and other active ingredients were stimulated much more by light as compared to dark. It is a well-known fact that light plays a key role in primary and secondary metabolism and various plant developmental processes. A positive correlation between increasing light intensity and levels of phenolics has been reported (Bennett and Wallsgrove, 1994). Ali and Abbasi (2014) reported that continuous light may turn the cell suspension cultures to stress condition and act as a triggering factor for enhanced accumulation of phenolic metabolites, which is in agreement with our results presented here. Similarly, positive effect of continuous light on anthocyanin production was reported by Chan et al. (2010) in cultures of $M e$ lastoma malabathricum. The cultures exposed to 10$\mathrm{d}$ continuous darkness showed the lowest pigment content, while the cultures exposed to 10 -d continuous irradiance showed the highest pigment content.

\section{Conclusion}

The present study revealed that light application stimulated Echinacea purpurea cell suspension cultures to accumulate more alcamide, caftaric acid and echinacoside than darkness did. Similarly, the number and dry weight of the cells cultured in light environment was more fostered than in dark. Furthermore, caffeic acid derivatives of chlorogenic, and cichoric acids could not be detected in Echinacea purpurea cell suspension cultures. The effect of light 
increased with increasing incubation time; the longer the period of culture, the higher the content of alcamide, caftaric acid and echinacoside. In conclusion, this study indicates that light application in cell suspension culture of Echinacea purpurea L. possess a great potential for increasing important secondary metabolites such as alkamide, caftaric acid and echinacoside.

\section{Acknowledgement}

We are thankful to Scientific Research Projects Unit (BAP) of Ordu University for providing support to this research, with the number of AR-1340 BAP Project.

\section{References}

Ahmad, N., Rab, A., Ahmad, N. 2016. Light-induced biochemical variations in secondary metabolite production and antioxidant activity in callus cultures of Stevia rebaudiana (Bert). Journal of Photochemistry and Photobiology B: Biology, 154: 51-56.

Ali, M., Abbasi, B.H. 2014. Light-induced fluctuations in biomass accumulation, secondary metabolites production and antioxidant activity in cell suspension cultures of Artemisia absinthium L. Journal of Photochemistry and Photobiology B: Biology, 140: 223 227.

Balcerowicz, M., Fittinghoff, K., Wirthmueller, L., Maier, A., Fackendahl, P., Fiene, G., Koncz, C., Hoecker, U. 2011. Light exposure of Arabidopsis seedlings causes rapid de-stabilization as well as selective post-translational inactivation of the repressor of photomorphogenesis SPA2. Plant Journal, 65: 712723.

Bennett, R.N., Wallsgrove R.M. 1994. Secondary metabolites in plant defense mechanisms. New Phytologist, 127:617-33.

Chan, L.K., Koay, S.S., Boey, P.L., Bhatt, A. 2010. Effects of abiotic stress on biomass and anthocyanin production in cell cultures of Melastoma malabathricum. Biological Research, 43:127-135.

Chaves, I., Pokorny, R., Byrdin, M., Hoang, N., Ritz, T., Brettel, K., Ahmad, M. 2011. The cryptochromes: blue light photoreceptors in plants and animals. Annual Review of Plant Biology, 62: 335-364.

El-Aal, M.S.A., Rabie, K.A.E., Manaf Hossam, H. 2016. The Effect of UV-C on Secondary Metabolites Production of Echinacea purpurea Culture in Vitro. Environmental Science \& Technology, 11(2): 465483.
Gehlot, A., Arya, I.D., Arya, S. 2017. Regeneration of Complete Plantlets from Callus Culture of Azadirachta indica A. Juss using Immature Flower Buds. Advances in Forestry Science, 4(1): 71-76.

Georgieva, L., Ivanov, I., Marchev, A., Aneva, I., Denev, P., Georgiev, V., Pavlov, A. 2015. Protopine production by Fumaria cell suspension cultures: effect of light. Applied Biochemistry and Biotechnology, 176(1): 287-300.

Gualandi, R.J., Augé, R.M., Kopsell, D.A., Ownley, B.H., Chen, F., Toler, H.D., Gwinn, K.D. 2014. Fungal mutualists enhance growth and phytochemical content in Echinacea purpurea. Symbiosis, 63(3): 111-121.

Halliday, K.J., Fankhauser, C. 2003. Phytochrome-hormonal signaling networks. New Phytologist, 157(3): 449463.

Heijde, M., Ulm, R. 2012. UV-B photoreceptor-mediated signaling in plants. Trends in Plant Science, 17(4): 230-237.

Kami, C., Lorrain, S., Hornitschek, P., Fankhauser, C. 2010. Chapter two-light-regulated plant growth and development. Current Topics in Developmental Biology, 91: 29-66.

Khan, M.A., Abbasi, B.H., Ahmed, N., Ali, H. 2013. Effects of light regimes on in vitro seed germination and silymarin content in Silybum marianum. Industrial Crops and Products, 46: 105-110.

Laloue, M., Courtois, D., Manigault, P. 1980. Convenient and rapid fluorescent staining of plant cell nuclei with “33258” Hoechst. Plant Science Letter, 17: 175-179.

Liu, R., Li, W., Sun, L.Y., Liu, C.Z. 2012. Improving root growth and cichoric acid derivatives production in hairy root culture of Echinacea purpurea by ultrasound treatment. Biochemical Engineering Journal, 60: 62-66.

Manayi A., Mahdi, V., Soodabeh, S. 2016. Echinacea purpurea: Pharmacology, phytochemistry and analysis methods. Pharmacognosy Reviews, 9(17): 63.

Moroff, G., Eich, J., Dabay, M. 1994. Validation of use of the nageotte: hemocytometer to count low levels of white cells in white cell reduced platelet components. Transfusion, 34: 35-38.

Murthy, H. N., Dandin, V.S., Zhong, J.J., Paek, K.Y. 2014. Strategies for enhanced production of plant secondary metabolites from cell and organ cultures. In Production of Biomass and Bioactive Compounds Using Bioreactor Technology, eds. K.Y.

Paek, H.N. Murthy and J.J. Zhong, pp. 471-508. Springer, Dordrecht, the Netherlands. 
Romero, F.R., Delate, K., Kraus, G.A., Solco, A.K., Murphy, P.A., Hannapel, D.J. 2009. Alkamide production from hairy root cultures of Echinacea. In Vitro Cellular \& Developmental Biology Plant, 45(5): 599604.

Shalitin, D., Yang, H., Mockler, T.C., Maymon, M., Guo, H., Whitelam, G.C., Lin, C. 2002. Regulation of Arabidopsis cryptochrome 2 by blue-light-dependent phosphorylation. Nature, 417(6890): 763-767.

Shohael, A.M., Ali, M.B., Yu, K.W., Hahn, E.J., Islam, R., Paek, K.Y. 2006. Effect of light on oxidative stress, secondary metabolites and induction of antioxidant enzymes in Eleutherococcus senticosus somatic embryos in bioreactor. Process Biochemistry, 41(5): 1179-1185.

Sreelakshmi, Y., Sharma, R. 2008. Differential regulation of phenylalanine ammonia lyase activity and protein level by light in tomato seedlings. Plant Physiology and Biochemistry, 46(4): 444-451.

Srivastava, P., Sisodia, V., Chaturvedi, R. 2011. Effect of culture conditions on synthesis of triterpenoids in suspension cultures of Lantana camara L. Bioprocess and Biosystems Engineering, 34(1): 75-80.

Tariq, U., Ali, M., Abbasi, B.H. 2014. Morphogenic and biochemical variations under different spectral lights in callus cultures of Artemisia absinthium L. Journal of Photochemistry and Photobiology B: Biology, 130: 264-271.

Weidler, G., Zur Oven-Krockhaus, S., Heunemann, M., Orth, C., Schleifenbaum, F., Harter, K., Hoecker, U., Batschauer, A. 2012. Degradation of Arabidopsis CRY2 is regulated by SPA proteins and phytochrome A. Plant Cell, 24: 2610-2623.

Winkel-Shirley, B. 2001. Flavonoid biosynthesis. A colorful model for genetics, biochemistry, cell biology, and biotechnology. Plant Physiology, 126(2): 485-493.

Wu, C.H., Murthy, H.N., Hahn, E.J., Paek, K.Y. 2007. Largescale cultivation of adventitious roots of Echinacea purpurea in airlift bioreactors for the production of chichoric acid, chlorogenic acid and caftaric acid. Biotechnology Letters, 29(8): 1179-1182.

Xu, C.G., Tang, T.X., Chen, R., Liang, C.H., Liu, X.Y., Wu, C.L., Wu, H.A. 2014. A comparative study of bioactive secondary metabolite production in diploid and tetraploid Echinacea purpurea (L.) Moench. Plant Cell, Tissue and Organ Culture (PCTOC), 116(3): 323-332.

Zhao, S.Z., Sun, H.Z., Chen, M., Wang, B.S. 2010. Lightregulated betacyanin accumulation in euhalophyte Suaeda salsa calli. Plant Cell, Tissue and Organ Culture (PCTOC), 102(1): 99-107. 